\title{
Efektivitas Penerapan Tanggung Jawab Sosial Perusahaan terhadap Pengembangan Usaha Mikro
}

\author{
Eka Travilta Oktaria ${ }^{(1)}$, Desi Derina Yusda ${ }^{(2)}$ \\ ${ }^{1,2}$ Universitas Mitra Indonesia \\ ekatravilta@umitra.ac.id,desiderina@umitra.ac.id
}

\begin{abstract}
Abstrak.
Usaha mikro memiliki peranan yang sangat vital di Indonesia saat ini terutama sebagai pendapatan asli daerah serta pendorong perekonomian di Indonesia. Sebagai salah satu alternative dalam pengembangan usaha mikro adalah dengan adanya penerapan tanggung jawab sosial perusahaan terhadap pelaku usaha mikro dalam rangka mendukung pengembangan usaha mikro. Tujuan dari penelitian ini adalah untuk mengetahui efektivitas penerapan tanggung jawab sosial perusahaan terhadap pengembangan usaha mikro Metode penelitian dalam penelitian ini adalah secara deskriptif kualitatif dimana hasil dari penelitian ini merupakan hasil dari fenomena yang terjadi disekitar kita dengan memperoleh data apa adanya. Analisis data menggunakan reduksi data, display data dan kesimpulan Adapun hasil dari penelitian ini adalah pendanaan yang dilakukan oleh persero dalam rangka memberikan pembiayaan CSR kepada usaha mikro sangat memberikan kesan positif dalam mengurangi permsalahan pembiayaan bagi usaha mikro pada khususnya. Sehingga dengan adanya pendanaan CSR ini maka usaha mikro dapat meningkatkan kembali kapasitas usaha yang semula hanya bersifat informal dapat menjadi formal.
\end{abstract}

Kata kunci:.Efektivitas, Penerapan,TanggungJawabSosial,Usaha Mikro.

\begin{abstract}
.
Micro business has a very vital role in Indonesia at this time, especially as regional income and driving the economy in Indonesia. As an alternative in the development of micro businesses is the application of corporate social responsibility to micro businesses in order to support the development of micro businesses. The purpose of this study is to determine the effectiveness of the application of corporate social responsibility to the development of micro businesses. The research method in this study is descriptive qualitative where the results of this study are the result of phenomena that occur around us by obtaining data as is. Data analysis using data reduction, data display and conclusions The results of this study are the funding carried out by the company in the context of providing CSR funding to microbusinesses really gives a positive impression in reducing financing problems for microbusinesses in particular. So that with the existence of this CSR funding, micro businesses can increase their business capacity which was originally only informal in nature can become formal.
\end{abstract}

Keywords: Application,Effectiveness,Micro business, Social Responsibility

\section{PENDAHULUAN}

Program pengembangan Usaha Mikro, Kecil, dan Menengah (UMKM) sebagai salah satu instrument untuk menaikkan daya beli masyarakat, pada akhirnya akan menjadi katup pengaman dari situasi krisis moneter. Pengembangan UMKM menjadi sangat strategis dalam menggerakkan perekonomian nasional, mengingat kegiatan usahanya mencakup hampir semua lapangan usaha sehingga kontribusi UMKM menjadi sangat besar bagi peningkatan pendapatan.(Anggraeni et al., 2013)

Dewasa ini pembangunan infrastruktur semakin meningkat seiring hal tersebut membangkitkan para pelaku usaha 
sektor UMKM memberikan kontribusi khususnya dalam peningkatan ekonomi di Indonesia. Seperti halnya dapat dilihat banyaknya UMKM yang menjadi usaha besar dan mampu bersaing dengan usaha sejenis bahkan sampai go-public di dalam pasar modal. Pasar modal adalah industri yang sangat dinamis, atraktif, selalu berubah dan mempunyai interdepedensi yang sedemikian tinggi dengan sektor jasa keuangan lainnya ditingkat domistik maupun global.(Oktaria, 2018)

Tanggung jawab sosial atau yang kita kenal dengan istilah Corporate Social Responsibility (CSR) perusahaan merupakan suatu pendekatan bisnis yang memberikan kontribusi terhadap pembangunan yang berkelanjutan dengan memberikan manfaat ekonomi kepada masyarakat baik secara sosial dan lingkungan bagi seluruh pemangku kepentingan. Tanggung jawab sosial merupakan komitmen bisnis untuk bertindak secara etis, beroperasi secara legal dan berkontribusi untuk meningkatkan kualitas kehidupan karyawan, masyarakat serta pelaku usaha mikro tentunya. Kegiatan Corporate Social Responsability menurut hujaimatul merupakan kewajiban bagi perusahaanperusahaan dalam kepeduliannya terhadap masyarakat dan lingkungan sekitar.(Fauziyah \& Fahrizi, 2019)

Usaha kecil dan menengah (UKM) merupakan salah satu bagian penting dari perekonomian suatu negara ataupun daerah. Berbagai upaya pengembangan UKM telah dilakukan, salah satunya dengan membangkitkan dan memperbanyak orang atau pengusaha baru di bidang UKM, sehingga masyarakat desapun diberi keterampilan dengan harapan keterampilan tersebut menjadi sebuah usaha kreatif yang memberi manfaat bagi perekonomian keluarga dan masyarakat desa. Selain itu, usaha kreatif tersebut juga dapat membukan kesempatan dan lapangan kerja baru bagi masyarakat.(Ananda \& Susilowati, 2019)
Perseroan berkomitmen untuk menerapkan tanggung jawab sosial seperti aspek ekonomi, pendidikan, sosial, lingkungan dalam berbagai macam program yang dimiliki oleh masing-masing perseroan yang telah berkontribusi dalam kampanye anti narkoba, penyiaran saluran televisi pemerintah, pemberian beasiswa, pemberian modal usaha bagi pelaku usaha mikro, bakti sosial maupun kegiatan donor darah guna membantu sesama.

Penelitian oleh Eva tentang Efektivitas Penerapan Tanggung Jawab Sosial Perusahaan PT BPRS Madina Mandiri Sejahtera hasil penelitian menunjukan Efektivitas penerapan tanggung jawab sosial perusahaan PT BPRS Madina Mandiri Sejahtera sesuai dengan kriteria yang dijadikan tolak ukur yaitu ketepatan sasaran program, sosialisasi program, tujuan 'Program dan pemantauan program bahwa untuk penerapan tanggung jawab sosial perusahaan (CSR) program untuk pelaku organisasi dan kesejahteraan sosial sudah berjalan efektif namun untuk program lingkungan alam tidak berjalan efektif. (Hafannafiah, 2018). Penelitian lain menunjukan analisis data menunjukkan bahwa umur listing perusahaan, kepemilikan institusional, kepemilikan asing, ukuran dewan komisaris, dan profItabilitas berpengaruh terhadap pengungkapan tanggung jawab sosial perusahaan sedangkan ukuran perusahaan, independensi komite audit, dan struktur modal tidak berpengaruh terhadap pengungkapan tanggung jawab sosial perusahaan.(Budiman, 2017). Dari penelitian tersebut bahwa penerapan tanggung jawab sosial menjadikan perusahaan berjalan efektif.

Oleh karena itu tanggung jawab sosial suatu perusahaan ini sangat erat sekali hubungannya dengan pembangunan ekonomi yang berkelanjutan terutama dalam bidang usaha sehingga dapat memberikan aspek positif terhadap usaha yang 
mengelami kesulitan. CSR yang selama ini digaungkan oleh pemerintah dan dunia internasional karena program CSR yang dilaksanakan bukan merupakan program CSR yang mendukung terlaksananya pembangunan ekonomi yang berkelanjutan. (Dr. Firdaus, S.H., 2016) Mengenai efektivitas penerapan tanggung jawab sosial ini sanagt memberikan dampak positif bagi para pelaku usaha mikro sehingga dapat memberikan pertumbuhan ekonomi baik di tingkat daerah maupun tingkat nasional agar perkembangan usaha terutama bagi usaha mikro dapat berjalan dengan baik pada khususnya sehingga usaha mikro dapat berkembang dengan adanya tanggung jawab sosial perusahaan yang membantu usaha mikro baik dalam hal modal maupun dalam hal penyuluhan teknis usaha yang memang belum didapatkan bagi usaha mikro pada khususnya.

Lebih lanjut dalam hal kontribusi perusahaan terhadap tujuan pembangunan berkelanjutan dengan cara manajemen yang berdampak pembangunan yang positif terhadap seluruh pemangku kepentingan dalam rangka tujuan pembangunan yang berkelanjutan baik yang bersifat jangka pendek maupun yang bersifat jangka panjang. Perhatian terbesar bagi perseroan terbesar adalah mengenai dampak terhadap pelaku usaha yang memberikan kontribusi bagi pelaku usaha mikro dan pelaku usaha lainnya sehingga perseroan dapat berperan lebih dalam mengembangkan usaha mikro dan usaha kecil lainnya sehingga dapat berkembang dan mampu untuk naik kelas ke usaha yang lebih besar lagi tentunya. Perusahaan atau corporate memegang peran yang sangat penting untuk ikut andil menyelesaikan permasalahan usaha mikro.(Kurniasari, 2015)

Usaha Mikro, Kecil, dan Menengah ( UMKM) merupakan kelompok yang telah mempunyai usaha meskipun skalanya kecil ataupun mikro. UMKM punya potensi untuk tumbuh besar sehingga mampu menyerap tenaga kerja tenaga kerja dan mengurangi pengangguran. Untuk itu dibutuhkan pemberdayaan pada kelompok usaha ini agar tumbuh dengan baik.(Satari, 2019)

Permasalahan yang penulis angkat dalam penelitian ini adalah bagaimana efektivitas penerapan tanggung jawab sosial perusahaan terhadap pengembangan usaha mikro? Sehingga pelaku usaha mikro yang semula bersifat informal dapat menjadi usaha yang sifatnya formal.

\section{METODE PENELITIAN}

Penelitian ini menggukan jenis penelitian kualitatif deskriptif. Fokus dari penelitian ini adalah utuk mengetahui efektivitas penerapan tanggung jawab sosial perusahaan Terhadap pengembangan usaha mikro. Objek dalam penelitian ini yaitu perusahaan pengembang usaha mikro persero. Teknik analisis data menggunakan analisis deskriptif.

\section{PEMBAHASAN}

Usaha mikro seperti persero telah diakui sangat strategis dan penting tidak hanya bagi pertumbuhan ekonomi tetapi juga untuk pembagian pendapatan yang merata. Karena peranannya yang sangat strategis dan penting, Indonesia memberikan perhatian khusus bagi perkembangan perkembangan mereka, termasuk membina lingkungan dengan iklim usaha yang kondusif, memfasilitasi dan memberikan akses pada sumberdaya produktif dan memperkuat vkewirausahaan serta daya saingnya. Untuk memperkuat usaha mikro, salah satu strategi yang penting adalah kemitraan.

Untuk membentuk kemitraankemitraan ini, peranan pemerintah dan instansi-instansi pendukung lainnya adalah strategis dan penting. Peranan pemerintah dapat dilakukan melalui penciptaan iklim 
usaha yang kondusif untuk menciptakan kemitraan dan dapat pula memberikan fasilitas dan dukungandukungan lain seperti misalnya fasilitas penciptaan keserasian (match making), menyediakan bantuan keuangan dan keperluan-keperluan yang lainnya untuk menjembatani kemitraan antara kedua pihak tersebut.(Soegiastuti, 2012)

Disamping pemerintah, peranan perusahaan perusahaan besar untuk memberikan suatu dukungan dan menyisihkan sebagian dari keuntungan bersih mereka guna pengembangan usaha mikro dan kecil yang dikenal dengan Corporate Social Responsibility (CSR) mungkin juga perlu dilanjutkan. Pembinaan CSR untuk pengembangan usaha mikro dan kecil telah menjadi salah satu pilihan strategis banyak negara berkembang agar supaya memperkuat dan meningkatkan daya saing usaha mikro dan kecil. Sudah diakui bahwa perusahaan-perusahaan besar tidak akan tumbuh berkembang dengan baik tanpa dukungan usaha mikro dan kecil. Oleh karena itu, usaha mikro dan perusahaanperusahaan besar harus selalu bekerjasama satu sama lain agar memanfaatkan peluangpeluang demi pertumbuhan dan kemakmuran masyarakat.

Perusahaan (Corporate) selalu menjalankan usaha dan berhubungan dengan masyarakat, baik masyarakat sekitar maupun masyarakat luas, baik masyarakat dalam arti umum maupun masyarakat dunia usaha, termasuk Usaha Mikro dan Kecil. Dalam konsep Corporate Social Responsibility (CSR) masyarakat termasuk usaha mikro dan kecil merupakan stakeholders dari perusahaan. Usaha mikro dan kecil sebagai stakeholders dari perusahaan berskala besar masih perlu diberdayakan. Selain dari itu usaha mikro dan kecil juga memiliki fleksibilitas yang tinggi jika dibandingkan dengan usaha yang berkapasitas lebih besar. Walaupun perusahaan usaha mikro dan kecil berskala menengah dan kecil, tidak berarti mereka tidak dapat berbagi kepada masyarakat maupun kepada perusahaan yang skalanya lebih kecil dalam program CSR.(Tresnati, 2014)

Perusahaan berskala besar, termasuk perusahaan yang berusaha di bidang apapun mempunyai tanggung jawab sosial untuk ikut memberdayakan usaha mikro dan kecil. Oleh karena itu, dalam penelitian ini dicari solusi atau jawaban tentang penerapan CSR bagi perusahaan berskala besar dalam pemberdayaan usaha mikro dan kecil, kendala implementasi penerapan pengembangan usaha mikro melalui program CSR, dan pengembangan usaha mikro dan kecil yang tepat dan berkeadilan melalui program CSR.(Suparnyo et al., 2013)

Di beberapa negara dibutuhkan laporan pelaksanaan CSR, walaupun sulit diperoleh kesepakatan atas ukuran yang digunakan untuk mengukur kinerja perusahaan dalam aspek sosial. Sementara aspek lingkungan apalagi aspek ekonomi memang jauh lebih mudah diukur. Banyak perusahaan sekarang menggunakan audit eksternal guna memastikan kebenaran laporan tahunan perseroan yang mencakup kontribusi perusahaan dalam pembangunan berkelanjutan, biasanya diberi nama laporan CSR atau laporan keberlanjutan (sustainability report).

Namun, dengan semakin berkembangnya konsep CSR dan metode verifikasi laporannya, kecenderungan yang sekarang terjadi adalah peningkatan kebenaran isi laporan. Bagaimanapun, laporan CSR atau laporan keberlanjutan (sustainability report) merupakan upaya untuk meningkatkan akuntabilitas perusahaan di mata para pemangku kepentingannya.

Skala dan sifat keuntungan dari CSR untuk suatu organisasi dapat berbeda-beda tergantung dari sifat perusahaan tersebut. Banyak pihak berpendapat bahwa amat sulit 
untuk mengukur kinerja CSR, walaupun sesungguhnya cukup banyak literatur yang memuat tentang cara mengukurnya. Literatur tersebut misalnya metode "Empat belas poin balanced scorecard oleh Deming. Literatur lain misalnya Orlizty, Schmidt, dan Rynes yang menemukan suatu korelasi positif walaupun lemah antara kinerja sosial dan lingkungan hidup dengan kinerja keuangan perusahaan.

Kebanyakan penelitian yang mengaitkan antara kinerja CSR (corporate social responsibility) dengan kinerja finansial perusahaan (corporate financial performance) memang menunjukkan kecenderungan positif, namun kesepakatan mengenai bagaimana CSR diukur belumlah lagi tercapai. Mungkin, kesepakatan para pemangku kepentingan global yang mendefinisikan berbagai subjek inti (core subject) dalam ISO 26000 "Guidance on Social Responsibility" yang lebih memudahkan perusahaan untuk menurunkan isu-isu di setiap subjek inti dalam standar tersebut menjadi alat ukur keberhasilan CSR.

Hasil Survei "The Millenium Poll on CSR" (1999) yang dilakukan oleh Environics International (Toronto), Conference Board (New York) dan Prince of Wales Business Leader Forum (London) di antara 25.000 responden dari 23 negara menunjukkan bahwa dalam membentuk opini tentang perusahaan, $60 \%$ mengatakan bahwa etika bisnis, praktik terhadap karyawan, dampak terhadap lingkungan, yang merupakan bagian dari tanggung jawab sosial perusahaan (CSR) akan paling berperan. Sedangkan bagi $40 \%$ lainnya, citra perusahaan \& brand image-lah yang akan paling memengaruhi kesan mereka. Hanya 1/3 yang mendasari opininya atas faktorfaktor bisnis fundamental seperti faktor finansial, ukuran perusahaan,strategi perusahaan, atau manajemen.

Lebih lanjut, sikap konsumen terhadap perusahaan yang dinilai tidak melakukan CSR adalah ingin "menghukum" (40\%) dan 50\% tidak akan membeli produk dari perusahaan yang bersangkutan dan/atau bicara kepada orang lain tentang kekurangan perusahaan tersebut.

$$
\text { Dana Corporate Social }
$$

Responsibility (CSR) untuk kewirausahaan bisa dikatakan dapat menjadi pemecah masalah sosial. Dengan memberikan edukasi kewirausahaan yang dapat menciptakan peluang usaha baru. Sehingga harapannya dari Dana CSR untuk kegiatan kewirausahaan membantu untuk meningkatkan perekonomian dan program ini dianggap mampu untuk mengembangkan perekonomian usaha mikro pada khususnya.(Sadewo, 2019)

Untuk membuat program CSR yang bersifat jangka panjang salah satunya dengan memanfaatkan dana CSR untuk kewirausahaan. Kegiatan pelatihan kewirausahaan dapat diberikan kepada karyawan, komunitas atau masyarakat yang membutuhkan pemberdayaan.

\section{KESIMPULAN DAN SARAN}

\section{Kesimpulan}

Penerapan tanggung jawab sosial perusahaan dilakukan dilakukan untuk memberikan pengembangan pembangunan terutama dalam aspek sosial dan ekonomi di Indonesia. Hal itu pun dilakukan oleh perseroan yang terdiri dari beberapa tahapan diantaranya penerapan pemberian pendanaan usaha, pemberian beasisea, perbaikan lingkungan disekitar lingkungan usaha atau bahkan memberikan bimbingan teknis mengenai usaha agar lebih optimal kembali.

Sehingga berdasarkan analisis diatas penulis menyimpulkan bahwa CSR dapat memberikan peranan tambahan terhadap peningkatan kapasitas usaha yang semula dari usaha informal menuju usaha formal sehingga penerapan CSR dianggap sangat efektif dalam peningkatan kapasitas usaha 
maupun pengembangan usaha mikro secara ekonomi maupun bantua sosial terhadap usaha mikro dan sangat efektif juga dalam pemberian penyuluhan teknis usaha atau manajaemen usaha yang baik

\section{Saran}

Adanya CSR tersebut akan menaikan pendapatan ekonomi daerah yang baik, selanjutnya memungkin kanterjadinya peningkatan kapasitas usaha yang lebih baik lagi. Namun terkadang penyaluran terhadap CSR masih minim akan informasi yang diberikan kepada para pelaku usaha serta masyarakat tentunya. Oleh karena itu, penulis menyarankan kepada perseroan agar dapat kembali memberikan perlakuan lebih terutama kepada masyarakat serta para pelaku usaha mikro agar dapat membuat informasi yang dapat dijangkau kepada lapisan masyarakat tentunya agar CSR perseroan tetap terus berjalan dengan baik dan para pelaku usaha terus berkembang.

\section{DAFTAR PUSTAKA}

Ananda,A.D\&Susilowati,D.(2019).Pengem bangan Usaha Mikro Kecil Dan Menengah (Umkm) Berbasis Industri Kreatif Di Kota Malang. Jurnal Ilmu Hukumrnal Ilmu Ekonomi, X(X), 120142.

Anggraeni, F. D., Hardjanto, I., \& Hayat, A.(2013). Pengembangan Usaha Mikro, Kecil, Dan Menengah (Umkm) Melalui Fasilitasi Pihak Eksternal Dan Potensi Internal. Jurnal Administrasi Publik (Jap), 1(6), 1286-1295.

Budiman, N. A.(2017). Faktor-Faktor Yang Mempengaruhi Pengungkapan Tanggung Jawab Sosial Perusahaan. JRAM, Prodi Akutansi, Fakultas Ekonomi UMB Yogyakartal(1). Https://Doi.Org/10.26486/Jramb.Vlil. 9

Dr. Firdaus, S.H., M.(2016).Penerapan Tanggung Jawab Sosial Perusahaan
Corporate Social Responsibility (Csr) Di Bidang Perkebunan Kelapa Sawit Pt. Tri Bakti Sarimas Dalam Rangka Meningkatkan Kesejahteraan Masyarakat Kabupaten Kuantan Singingi Provinsi Riau. Jurnal JOM Iii, $1-15$.

Fauziyah, H., \& Fahrizi.(2019).Program Corporate Social Responsibility (Csr) Ptpn Vii, Lampung Sebagai Kegiatan Pemberdayaan Masyarakat Terhadap Upaya Meninmgkatkan Pendapatan Usaha Industri Keripik Di Kota Bandar Lampung. Ekombis Sains Jurnal Ekonomi Keuanga Dan Bisnis Universitas Sang Bumi Ruwa Jurai, 1689-1699.

Hafannafiah, E.(2018). Efektivitas Penerapan Tanggung Jawab Sosial Perusahaan Pt Bprs Madina Mandiri Sejahtera. Universitas Islam Indonesia Kurniasari, N.D.(2015).Program Csr Berbasis Pemberdayaan Masyarakat (Untuk Meningkatkan Produktivitas Usaha Mikro, Kecil Menengah Di Madura ). Jurnal Neo-Bis, 9(1), 98109.

Oktaria, E. T. (2018). Pengembangan Umkm Dalam Pembiayaan Mikro Berbasis Koperasi Dalam Rangka Peningkatan Ekonomi Di Indonesia. Jurnal Ekombis Sains, $3(9), \quad 35 \quad 43$. Https://Doi.Org/10.1017/Cbo9781107 415324.004

Sadewo, H. S. Anrinawati Dan F. S. (2019). Pengembangan Model Kemitraan Umkm Dengan Mitra Dengan Usaha Skala Sedang Dan Besar Di Jawa Timur Melalui Cooperate Social Responsibility. Jurnal Inovasi Kementerieran Dalam Negeri, 3 No. 2. Satari,S.(2019). Pemberdayaan Usaha Mikro, Kecil Dan Menengah (Umkm) Melalui Program Csr Pt Indocement (Studi Kasus Di Blok Kebon Gedang Desa Ciwaringin Kecamatan Ciwaringin Kabupaten Cirebon. Jurnal 


\section{EKOMBIS Sains}

Empower, Jurnal Pengembangan Masyarakat Islam.

Soegiastuti, J.(2012).Penerapan Strategi Corporate Social Responsibility (Csr) Untuk Memperkuat Usaha Mikro, Kecil Dan Menengah (UMKM). Jurnal Ekonomi Dan Manajemen, 25(1), 96106.

Suparnyo, Wicaksono, A., \& Wiwit, A. (2013). Tanggung Jawab Sosial Perusahaan (Coomperate Social Respnsibility) Dan Implementasinya.
Jurnal Sosial Dan Budaya, Vol 6, No.1 Tresnati, R.(2014).Kajian Tentang Penerapan Corporate Social Responsibility (Csr) Oleh Ukm (Usaha Kecil Dan Menengah) Di Indonesia \& Aplikasinya. Jurnal Manajemen Dan Bisnis (Performa)Vol.XI No. 1. 


\section{EKOMBIS Sains}

